\title{
Latino Parents' Perspectives on the Life Trajectories of Mixed-Status Children
}

\author{
Joseph G. Grzywacz ${ }^{1}$ Edgar Apanecatl-Ibarra年, Ebony Iheanacho ${ }^{1} \cdot$ Kinsey E. Pocchio $\mathbb{1}^{1}$ • \\ Jonathan R. Cardamone ${ }^{3,5} \cdot$ Michael J. Merten ${ }^{3,6} \cdot$ Martha I. Zapata $^{3,7}$
}

Received: 13 November 2019 / Revised: 4 November 2021 / Accepted: 5 November 2021 / Published online: 7 January 2022

(C) The Author(s), under exclusive licence to Springer Science+Business Media, LLC, part of Springer Nature 2021

\begin{abstract}
Many immigrant Latino families have one or more U.S. -born children and at least one foreign-born non-citizen child. Contextual theories of human development would argue that these siblings would have very different life trajectories by virtue of their citizenship status or lack thereof. However, researchers and policy-makers know very little about the home environment of mixed-status siblings. Using data from in-depth personal interviews, this study examined parental perceptions of the life trajectories of mixed-status youth. Participants were 18 parents with at least one adolescent between the ages of 10-18 residing at home. Using grounded theory, two broad themes emerged. First, parental perceptions of children's life trajectories based on citizenship and parental concerns' regarding their children's mixed legal status. Within this first theme, parents discussed youth's educational opportunities, job prospects, health care access, and travel restrictions. The second theme was parental concerns' about their children's citizenship status; ambivalence about migrating to the United States; and coping with fear and anxiety. Results of this study highlight the pervasive influence of immigration policies and practices on family dynamics and child development, the risk they posit to youth development and individual family resilience.
\end{abstract}

Keywords Immigrants $\cdot$ parent-child relationships $\cdot$ sibling relationships $\cdot$ Latino families

\section{Highlights}

- Little is known about how the absence of legal authorization to reside in the U.S. undocumented status affects developmental outcomes across life domains and stages.

- Parents of children without legal authorization to reside in the U.S. view "school" or educational advancement as a "Pipeline to Nowhere".

- Children's access to basic health care differs for children with and without legal authorization to reside in the U.S.

- Parents, regardless of their documentation status, see better life chances for children with legal authorization to reside in the U.S. relative to undocumented children.

- Political debates about the merits of the Deferred Action for Child Arrivals (DACA) overlook the developmental harm to the health and development of undocumented children.

Joseph G. Grzywacz jgrzywacz@fsu.edu

1 Department of Human Development and Family Science, Florida State University, Tallahassee, USA

2 Department of Higher Education \& Student Affairs, Oklahoma State University, Stillwater, USA

3 Department of Human Development and Family Science, Oklahoma State University, Stillwater, USA
4 Present address: Center for Intercultural Reflection and Social Action, the Universidad Iberoamericana Puebla, Puebla, Mexico

5 Present address: Families Matter DSM, LLC, Des Moines, USA

6 Present address: Department of Child, Youth, and Family Studies, University of Nebraska-Lincoln, Lincoln, USA

7 Present address: Uma Tulsa, Inc, Tulsa, USA 


\section{Parental Perspectives on the Life Trajectories of Mixed-Status Latino Siblings}

Mixed status families-binational families wherein some members are United States (U.S.) citizens or legal residents, but other members are not-comprise a substantial segment of the Latino population living in the U.S. The Pew Hispanic Center estimates that 16.6 million people in the U.S. live in families where at least one member lacks legal authorization to reside in the U.S. or is "undocumented" (Taylor, Lopez, Passel, \& Motel, 2011). Of people living in mixed-status families, 11.3 million are without legal authorization to reside in the U.S. and have lived in the country for 10 years or more (Passel, Cohn, Krogstad, \& Gonzalez-Barrera, 2014). Approximately 4.5 million U.S.born children under 18 years of age live with at least one parent who is not legally authorized to be in the U.S. (Passel et al., 2014). Immigrants without documentation are disproportionately Mexican-born (58\%) and more likely to have minor children living at home (46\%) than either immigrants without legal authorization to reside in the U.S. (38\%) or U.S.-born adults (29\%) (Taylor et al., 2011).

There are a significant number of individuals in the U.S. living in mixed-status families. The developmental trajectories for youth raised in families where all family members have the rights and privileges inherent of citizens or legal residents are likely different from those raised in families where one or more members lack legal authorization to be in the country. Regardless of whether it is conceived of as a feature of the macrosystem (Bronfenbrenner, 1979) that shapes person-environment interactions, a defining feature of the sociohistorical context (Elder, 1998), or as a basis of social stratification and subsequent "fundamental cause" (Link \& Phelan, 1995), the legal liminality of living in a mixed-status family likely compromises optimal development (Castañeda, 2015). Nevertheless, Suárez-Orozco and Yoshikawa (2013) pointed out, "there is much unknown about how undocumented status affects developmental outcomes across domains, life stages, and contexts" (p. 71).

This study used grounded theory (Strauss \& Corbin, 1990) to understand Latino parents' perceptions of siblings' challenges and opportunities with different legal status. Specifically, we wanted to identify parental awareness of the challenges faced by their non-U.S. citizen children who are unauthorized aliens, opportunities afforded to their U.S.born children who are U.S. citizens, and parental concerns about both citizen and non-citizen children. Given the nascency of research in this area, the intention is not to arrive at a theory of mixed-status families; instead, this research sought to generate critical concepts relevant to such a theory. Despite longstanding issues leading to discussions of comprehensive immigration reform, foreignborn children of immigrant parents without legal authorization to reside in the U.S. are also without authorization themselves and, like their parents, have very few legal recourses at their disposal to gain legal status (Castañeda et al., 2015; Motomura, 2006).

DACA, otherwise known as the Deferred Action for Childhood Arrivals, began providing some protections and opportunities for foreign-born children raised in the U.S. Barack Obama authorized DACA in 2012 to give qualified, individuals without legal authorization to reside in the U.S. relief from deportation, work permits, and temporary use of social security numbers. DACA does not provide individuals with a way to become legalized citizens at this time (Gonzales, Terriquez, \& Ruszczyk, 2014). Since its inception, the long-term viability of DACA remains in question and has been very contested within political agendas. In particular, the presidential elections that began in 2015 began specific uncertainty regarding the program's future due to Donald Trump's plans to end the program if elected (Patler, Hamilton, Meagher, \& Savinar, 2019).

\section{Developmental Implications of Legal Liminality}

Menjívar (2006) conceived of legal liminality as the ambiguous space occupied by immigrants who, whether holding legal authorization to reside in the U.S. or not, live their daily lives as though they were citizens. Legal liminality is characterized by immigrants keeping jobs and having taxes deducted from their paychecks, yet they cannot access citizens' rights. An emerging body of literature suggests that mixed-status families' legal liminality may undermine child adjustment and well-being (Suárez-Orozco et al., 2011; Yoshikawa \& Way, 2008). Chavez and colleagues (2012) identified family stress, uncertainty about the future, and social isolation as prevalent in adults and children living in mixed-status families. Legal liminality may impede typical development (Yoshikawa, Godfrey, \& Rivera, 2008) and increase the risk for maladjustment (Gonzales, Suárez-Orozco, \& Dedios-Sanguineti, 2013). Non-citizen children in mixed-status families, like their parents without legal authorization to be in the country, have lower access to health care (Castañeda, 2015; Raymond-Flesch, Siemons, Pourat, Jacobs, \& Brindis, 2014). Children without legal authorization to reside in the U.S. are less likely to graduate from high school and enroll in college (Greenman \& Hall, 2013), they have fewer educational opportunities (Gonzales, 2010; Gonzales \& Suárez-Orozco, 2009), and reduced labor market opportunities (Abrego \& Gonzales, 2010) than children who are citizens. Youth without legal authorization to reside in the U.S. may experience greater exposure to chronic stressors, they may confront more stigma and isolation because of their legal 
status, and they more frequently miss opportunities and milestones that mark the transition to adulthood (Abrego, 2011; Castro-Salazar \& Bagley, 2010; Gonzales, 2011; Gonzales \& Suárez-Orozco, 2009).

Studies of youth without legal authorization to be in the U.S. and mixed-status families have explored parents' perceptions of how their non-U.S. citizen children's life trajectories might differ from their U.S.-citizen children. However, many unanswered questions remain for this rapidly growing segment of society. As in most families, parents without legal authorization to reside in the U.S. profoundly impact their children's development (Sigel, McGillicuddy-DeLisi, \& Goodnow, 2014; Anderson \& Stevenson, 2019). Typically, immigrant Latino families show the collectivist ideals regarding familism and interdependence that are commonly expressed in their countries of origin (Suárez-Orozco, Motti-Stefandini, Marks, \& Katsiaficas, 2018). Despite clear evidence that parents try to shield their children from the burden of family members' documentation situation(s) (Chavez, Lopez, Englebrecht, \& Anguiano, 2012), the pernicious nature of legal insecurity creates an incredibly stressful situation for children in families where all members are without legal authorization to reside in the U.S. as well as mixed-status families (Abrego, 2019).

\section{Parental Influences on Youth's Developmental Outcomes}

A robust body of literature has established parents' strong influence on youth's developmental outcomes (Morris, Cui, \& Steinberg, 2013; Steinberg \& Morris, 2001). Children interpret various verbal and nonverbal messages from their parents and making meaning of these messages in multiple ways (Anderson \& Stevenson, 2019). Parents shape youths' self-regulation (Eisenberg, Zhou, Spinrad, Valiente, Fabes, \& Liew, 2005; Fosco \& Grych, 2013), emotional development (Grusec, 2011), and social competence (Leidy, Guerra, \& Toro, 2010). They also influence youth's goal orientation (Gonzalez \& Wolters, 2006; Gonzalez, Doan Holbein, \& Quilter, 2002), academic motivation (Alfaro, Umaña-Taylor, \& Bámaca, 2006; Gonzalez-DeHass, Willems, \& Holbein, 2005), and performance (Yamamoto \& Holloway, 2010), as well as self-esteem (Bámaca, UmañaTaylor, Shin, \& Alfaro, 2005; Plunkett, Williams, Schock, \& Sands, 2007) and emotional well-being (Elgar, Mills, McGrath, Waschbusch, \& Brownridge, 2007; Milevsky, Schlechter, Netter, \& Keehn, 2007). Moreover, parents may support youth's academic (Plunkett, Henry, Houltberg, Sands, \& Abarca-Mortensen, 2008; Swanson, Valiente, Lemery-Chalfant, \& Caitlin O'Brien, 2011), and emotional resilience (Armstrong, Birnie-Lefcovitch, \& Ungar, 2005).
Despite this well-developed body of evidence, less is known about parents' beliefs surrounding the challenges and opportunities created by citizenship or the lack thereof among children in immigrant families. Knowledge of parents' expectations for their children and subsequent behaviors in parenting U.S. citizen and non-citizen children is essential to forecast potential long-term consequences for this rapidly growing immigrant families segment and is imperative to serving their needs.

\section{Method}

Data for this analysis came from the FARO Project (Broken Families Project). This mixed-methods study examined family immigration status and its potential implications for adolescent emotional and behavioral health among Latinos in Oklahoma. The University's Institutional Review Board approved all recruitment and data collection procedures. Also, researchers obtained a Certificate of Confidentiality from the National Institutes of Health to protect study participants' anonymity.

\section{Recruitment}

One of the canons of grounded theory is ensuring variability in the concepts of interests (Corbin \& Strauss, 1990); consequently, study participation was limited by only two criteria. First, participants had to be adults who immigrated from Mexico or Central America or the spouse/partner of an immigrant from these regions. Second, potential participants needed to have a child between the ages of 10 and 18 . These criteria ensured variability in terms of time spent in the U.S. and direct or indirect experience with mixed-status families in various configurations (e.g., marriages where one spouse has legal authorization to reside and the other does not, families with U.S.-born children but parents lacking legal authorization to reside in the U.S., families with both U.S.-born and foreign-born children who lack legal authorization to reside in the U.S.). Participants were identified and recruited using a purposive sampling approach that included community outreach activities targeting Latino families (e.g., health fairs in conjunction with visits from the Mexican Consulate) co-sponsored by the university hosting the study $(n=10)$. A small number $(n=$ 2) of participants were members of the building cleaning staff at the university and consequently known by the research team. The remaining participants were identified and recruited $(n=6)$ based on referrals from other study participants.

One of two Latino study team members, both immigrants, and naturalized U.S. citizens, recruited all participants. Both individuals involved in participant recruitment 
had substantial experience conducting research or providing services to the immigrant Latino community. The trust and rapport from "being known" to the community are often considered essential when researching marginalized groups (Furman et al., 2009). The team members responsible for recruiting provided potential participants information about the study and, for individuals who demonstrated interest in study participation, screened for the inclusion criteria. Recruiters invited individuals who met the inclusion criterion to participate and sign an informed consent in the participants' primary language. This process allowed the research team to manage the pace of recruitment to enable data collection and analysis to proceed iteratively (Corbin \& Strauss, 2008).

\section{Data Collection}

Two trained, foreign-born interviewers collected all study data through face-to-face semi-structured in-depth interviews conducted between July 2013 and February 2014. The interviews were completed in a private location, typically participants' homes or another place of participants' choosing, and facilitated using a semi-structured interview guide to elicit participants' expectations and beliefs about raising children with different documentation status. The interview guide consisted of vignettes of hypothetical immigrant families with varying configurations of mixed-documented status. All data were collected during the interview process; no self-administered questionnaires of any type were administered. Data for this analysis came from two vignettes depicting two siblings. The first vignette depicted mixed-status siblings (i.e., one foreignborn living in the U.S. without legal documentation, the other a U.S.-born citizen) being stopped by the police. The second vignette depicted the same siblings being sick and needing medical care. Interviewers used the vignettes to introduce real situations in the community for discussion while also being attentive to the fact that immigrants may not want to selfdisclose personal experiences. In essence, the vignettes allowed individuals to talk about themselves in a neutral, "third-party" way, thereby providing flexibility in sampling different concepts presented by participants in the context of the interviews (Corbin \& Strauss, 2008). The interview guide was created in English, translated into Spanish by a native Spanish speaker, and then back-translated by a native English speaker.

Following each vignette, the parents were asked questions such as: "What would be Mario/Maria's parents' major concern about him/her? Why?", "How do you think Mario/Maria feels about his/her education?", "Will they take both boys/girls to the doctor? Why or why not"? What do you think will happen to Mario/Maria?" "Will Luis/ Luisa receive a ticket, or will he be taken to jail and be deported? Why? Why not?". The children in this study were asked the same set of questions as the parents.
Several strands of evidence speak to the trustworthiness of collected data. The interviewers met regularly with each other and the faculty advisor throughout data collection to discuss ideas emerging from the interviews and identify additional areas to probe future interviews. Several participants became highly emotional during the interview, suggesting the vignettes were a useful tool for eliciting beliefs or experiences that were very real to participants. All participants finished their interviews, and some expressed gratitude for the opportunity to "tell" their stories and "be heard". Indeed, the opportunity to provide testimonio (testimony) or a narrative account of experienced struggles and triumphs have been characterized as a form of empowerment for members of marginalized communities (Mangual Figueroa, 2013). After the interview, participants were compensated $\$ 20$ and given a list of free or reduced-fee legal and social services in the area and free counseling services offered by Spanish-speaking staff through the University's Counseling Center.

\section{Data Analysis}

A Mexican national graduate student pursuing a doctoral degree in Education transcribed recorded interviews verbatim in Spanish. Transcription of the interviews by a native Spanish speaker from Mexico was essential to ensure fidelity in conveying spoken language to written language (Hernández, Nguyen, Casanova, Suárez-Orozco, \& Saetermoe, 2013). Transcripts were reviewed for integrity and accuracy by one author-a Colombian immigrant and naturalized U.S. citizen who earned a doctorate in Human Development and Family Science while completing this research. A team of four individuals analyzed the data: the two individuals already characterized, one bilingual Human Development and Family Science graduate student who worked with youth in Guatemala, and a non-Spanish speaking faculty member who has researched the immigrant Latino community for 15 years.

The research team analyzed the interview transcripts following practices advocated by grounded theory, specifically through open, axial, and selective coding (Corbin \& Strauss, 2008). First, the two foreign-born members of the team read the interviews independently to identify salient topics. They met at least two times to discuss their findings with the faculty advisor. The contrast in the life trajectories of U.S.-born citizen children and their foreign-born, siblings without legal authorization to reside in the U.S. was identified as a salient topic by presenting selected segments from the transcripts translated to English. Next, the two foreignborn members of the team independently read the transcripts to extract all segments in which parents discussed the opportunities and challenges associated with U.S. citizenship or the lack of it (i.e., axial coding). Although the 
vignettes used in the interview guide elicited many of these segments, other segments were not.

Next, the research team's foreign-born members compared their lists of text segments extracted from the interviews to ensure inter-rater reliability (Corbin \& Strauss, 2008). This comparison occurred in a meeting with the faculty advisor who could pose unbiased questions of the ideas contained in each segment because he could not read Spanish. A coding scheme was then developed and applied to all text segments by the two foreign-born research team members. They then met again with the faculty advisor to evaluate coding consistency and consider revisions to the coding scheme. Coding disagreements were agreed upon in these meetings through a consensus process. Another member of the research team-a U.S. born non-Latino doctoral candidate bilingual in English and Spanish-also participated in this meeting to ensure the ability to verify the accuracy of the conceptual themes in the data identified by the two foreign-born research team members. Inter-rater agreement was $82 \%$, yielding high confidence that data analysis is unbiased. Team member complementarity in terms of nativity, fluency in written and spoken Spanishincluding unique dialects and idioms of predominantly immigrants from rural Mexico-and distinct types of experiences with Latino families and immigrants created a feedback loop necessary to prevent bias throughout data analysis (Corbin \& Strauss, 2008).

\section{Participants}

We set out to interview 40 parents. However, we stopped at 18 when we realized that we had reached thematic saturation (Creswell, 2007), meaning data was collected until new information was no longer surfacing in the interviews. Of these 18 parents, eight had both U.S.-born and foreign-born children, another eight had only U.S-born children, and two had only foreign-born children. The findings reported in this study originate primarily from the eight parents with mixed-status children. However, consistent with a core canon of grounded theory (Corbin \& Strauss, 1990), the data analysis included the entire sample. All study parents were able to comment on these particular experiences, either in terms of perception or direct experience with friends and network members with mixedstatus children. Parents with mixed-status children were mothers (7 Mexican-born and 1 Honduran-born), ranging in age from 31 to 53. Six of the women were married, one was living with her partner, two were divorced, and one was separated from her husband. The women had been living in the U.S. for between 10 and 26 years; all were without legal authorization to reside in the U.S. The team used data from the 10 parents who had either U.S.-born children or foreign-born children to triangulate (Miles \& Huberman, 1994) findings obtained from mixed-status siblings' parents. Two of these parents were Mexican-born men with U.S.-born children. One was an Argentinian-born woman reared in the United States who had U.S.-born children. Another participant was a U.S.born woman, the child of Mexican-born parents, living as married with a Mexican-born man, and later had a U.S.-born child. The average number of children per participant was 3.9 (range, 2-5); the median number was 5. When asked about their education, most parents reported completing primary education, which is 6th grade in many Latin American countries.

\section{Results}

Two broad themes emerged from the analyses: parental perceptions of children's life trajectories according to U.S. citizenship, or lack thereof, and parental concerns regarding the mixed legal status of their children. Within the first theme, parents discussed the youth's educational opportunities, job prospects, health care access, and travel restrictions. The second theme encompassed parental concerns about citizen and non-citizen children, ambivalence about migrating to the U.S. and coping with fear and anxiety.

\section{Theme I: Legal Status and Youth's Life Trajectories}

\section{School to Nowhere Pipeline: Blocked Educational Opportunities}

Parents' worried about non-citizen children's future due to diminished educational prospects and their effect on youth's motivation to perform in school. Parents were concerned that their children felt they had no future. This feeling usually started around middle adolescence and quelled children's drive to study. Some adolescents qualified for deferred action of child arrivals (DACA), but this path was impossible for some families. A mother described the family's distress from the perception of a blocked path to education for her daughter, despite being an excellent student and the relief brought about by DACA.

During high school, my daughter felt very, very frustrated. She would ask me, "What am I going to do once I graduate?" I would say, "Daughter, what do you want me to do? I cannot do anything". I wanted her to have that door open so that she could study. She persevered, graduated, and applied for DACA. When she got her permit, the next day, she got her driver's license and started going to college at night. I think that now she feels she belongs here.

There was a collective opinion among parents that citizen children "had all the opportunities" to study and achieve 
whatever they wanted. Whether they took advantage of such opportunities was another matter. By contrast, noncitizen children were viewed as high being at risk for underperforming and dropping out of school. The mother of two sons who had been deported to Mexico in their late adolescence/young adulthood attributed her sons' dropping out of school and then partying and drinking excessively to the young men's realization that they "had no future". Another mother encapsulated her non-citizen child's educational outcome in this way:

My son was a smart kid, but not having documents really traumatized him. It ended his dreams. A teacher once told me, "Your son is very intelligent. Talk to him; tell him to come to school. If he does well academically, I'm going to help him get a scholarship. Tell him not to throw away his future". But he would say why should I work hard in school if he could not continue studying.

Some parents were aware that their children could attend college in Oklahoma if they could pay full tuition, usually at a non-state resident rate, but none could afford it. Sometimes, parents openly shared their inability to pay nonresident tuition for the child. For example, one participant reported, "my daughter wants to continue her studies, but she cannot .... we do not have enough money for [postsecondary] education". In other cases, parents tried to sustain their children's hopes for the future.

My son is now in high school. He asks me, "Do you think I will be able to continue my studies [after high school]"? I tell him, "I do not know, son, but stay motivated and try to go as far as you can, and... [voice trailing] we will see what happens ahead". Yes, my son asks me that often [voice trailing].

Despite the financial obstacles to higher education facing their non-citizen children after high school, parents felt reassured about their children's U.S. education, regardless of the level completed. Parents believed their children were getting better schooling than parents received, and better than the children would have received in their countries of origin. Most parents felt that by getting their non-citizen children to graduate from high school and learn English, they had fulfilled, at least partially, their goal of giving them a better life and more opportunities. A common belief among parents was the intrinsic value of education and its potential to contribute to a better future.

I tell my son, "If you study, if you apply yourself, God is going to help you. First of all, have faith in God and apply yourself, do well in school. Getting an education, by itself, provides some security".

\section{"Even to Get a Bad Job You Need Papers": Job Prospects}

Parents held the collective opinion that finding a job was one of the main challenges non-citizen children would face in adulthood, independently of educational attainment. Without documents, parents anticipated that their noncitizen children would face difficulty finding and keeping good-paying and satisfying jobs, work harder than people with documents, and likely suffer exploitation by employers. One mother said, "It does not matter how simple or low rank the job might be, you are asked for papers [documentation]. In [fast food chain], to get a badly paid job, you must bring a valid Social Security Number". Another mother described the working world potentially awaiting her non-citizen child this way:

Undocumented persons are not treated the same as documented ones, even when given a chance to work. Because they do not have papers, they are given more tasks to do, but they are not promoted. They remain dishwashers. They are mistreated; employers know that workers cannot do anything. The workers stay just because they need the job.

The prospect of youth's unrealized lives was emotionally tricky because all parents stated that they had brought their non-citizen children to the U.S. to "give them a better future". Some parents expressed feelings of ambivalence, although not outright regret, for having brought their noncitizen children to the U.S.

Sometimes, I feel sad because I used to think, well, I will go there [to the U.S.] to get ahead in life, give them [children] a little bit more, something better. But the truth is that sometimes I regret it [having moved here], sometimes, I do not know whether I made the right decision for them.

\section{"How Are We Going to Pay for That"? Access to Health Care}

Parents felt they did not have to worry about meeting their citizen children's health care needs because they "usually had some health coverage".

One does not have to worry too much about a child who is legal. For example, my children have SoonerCare [Oklahoma's insurance for low-income children]. It covers whatever thing, God forbid, that might 
happen to my children. Even if it's a simple fever, SoonerCare covers them.

The health care needs of non-citizen children were much more difficult for parents to meet. One mother commented, "For any Latino family with an undocumented child, as in my case, it's very difficult to live in the U.S". The first line of action generally included home remedies, products sold at Mexican stores, antibiotics, and over the counter medications. One participant noted, "There are lots of Mexican medications, and they say they are for inflammation, and a lot of people try them because you do not have insurance". Non-citizen children without insurance went without regular checkups, dental care, or eyeglasses as parents only took them to the doctor when they were very sick. Visits to clinics and hospitals were fraught with difficulties due to the lack of insurance coverage, lack of valid identification, and high medical care costs. Several parents described how parents of non-citizen children would delay getting medical care until they felt it was essential. A parent said, "When my [Mexican-born] child gets sick, I start pondering: 'How much are they going to charge me?', But when my other child [U.S.-born] gets sick, I just say, 'Let's go to see the doctor". Overall, parents hoped that there was a way to buy health insurance for their non-citizen children. A mother, speaking for herself and her non-citizen children explained,

I wish there were some sort of health insurance available to us [individuals without documents] and affordable because many times, one does not go to the doctor for lack of coverage. Doctors are too expensive. One does not go to the doctor until one is really sick, and then the disease is too advanced because one did not go to the doctor on time.

\section{"You Cannot Go:" Travel Restrictions}

The need to drive to school or work combined with the impossibility of obtaining a driver's license and the threat of potential encounters with the police while driving were major concerns parents had about their non-citizen children. The mother of a 15-year-old Mexican-born boy stated,

I keep thinking, what is my son going to do to get a driver's license? Because one as Latino is always alert, fearful, wondering, what am I going to do if a police officer stops me? And the time will come when my son will want to drive, and it's a need. I want my son to drive because I would not have to leave my work at a certain time to come home and take them [the younger children] to school.
The lack of valid U.S. identification documents also made it dangerous for family members to travel long distances by car and restricted airplane traveling. Therefore, families could not travel together, and non-citizen children would forgo everyday experiences among middle-class U.S. families, such as traveling to participate in school competitions, family vacations, and visiting relatives in other states or their native countries. Of particular concern for parents was children's inability (and their own) to see family members in their country of origin, particularly aging grandparents or sick relatives. Citizen children sometimes had difficulty understanding why some family members could travel, but others could not.

My [U.S.-citizen] son has been to Mexico; he has his grandparents and cousins there. Sometimes, he tells me, "I want to go to Mexico again, but with you". I tell him, "Honey, I cannot go". He gets sad and tells me, "I am going to grow up, mom, and I will fix your papers so you can visit Mexico".

Parents described family members' contrasting feelings about the differential ability of mixed-status siblings to travel. One explained how difficult it was on non-citizen children to have their U.S. citizen siblings visit extended family members in their country of origin; simultaneously, the mother felt happy that her U.S. citizen children were able to have a pleasure she could not have.

It saddens my older [non-citizen] daughters that their younger [U.S. citizen] siblings can often go to Mexico. They go to visit my mother and my husband's parents, sometimes for two or three weeks at a time. My daughters say, "Lucky them that can go and visit". On one hand, that saddens me. On the other hand, it makes me happy that my younger children can see their grandparents.

\section{Theme II: Parental Concerns about Mixed-Status Children}

\section{"We Treat Them the Same:" Parallel and Divergent Trajectories}

Parents of mixed-status children nurtured their youngsters' life aspirations and goals regardless of citizenship status and "treated them the same". However, as children grew older, the privileges afforded by U.S. citizenship and the legal, social, and economic exclusion that comes with lacking legal authorization to reside in the U.S. became apparent to youth; consequently, "equal treatment" became unsustainable. Some parents had not 
disclosed their immigration status to their non-citizen children and had to do so when children were trying to meet developmental tasks, such as driving or planning for college. Other parents had told their U.S. citizen and non-citizen children about their respective statuses when they were little. Still, differences in privileges or lack thereof as a function of U.S. citizenship only became evident when non-citizen children reached developmental milestones.

We told our [mixed-status] children the truth since they were little, who was a U.S.-citizen and who was not; we told [non-citizen son] he did not have papers. Even so, we tried to raise them the same, without any difference. However, when they started growing up and had to give a Social Security Number (SSN) for various reasons, my [citizen son] started realizing that he had an SSN whereas his brother did not. As a mother, I feel that there might be some jealousy between them; but one tries to put makeup on the situation, so to speak.

Parents were pained by being unable to give their mixedstatus children some opportunities. Nevertheless, they were glad they could offer their citizen children, at least, the chances that initially motivated migration to the United States.

\section{Parental Concerns about Citizen Children}

Parents stated that they "did not have to worry too much" about citizen children's access to educational and economic opportunities. However, parents worried about their citizen children's moral education and ability to stay on the "good path" of life.

Children born here have many benefits. For example, if they want to attend college, they can get a scholarship. One's worry is that they do not quit school; that they walk along the good path. Here in the United States, there are a lot of drugs, so parents have to work on keeping their children away from drugs and gangs, make them respect their parents and [noncitizen] siblings, make them respect others [outside of the family] so they, in turn, can earn their respect, do not offend anyone, be humble.

Parents wanted to convey to their citizen children the importance of "not wasting the opportunities" bestowed upon them by their U.S. citizenship instead of using them to better themselves and their future family. A parent described how he talks to his citizen child:

Andale [move] son! Study and better yourself. Look, you are from here; you could have a good job, earn good money, and support your [future] family. Apply yourself so you can give your future family a good life, so you do not have to go through the hardships we endure. If you do not get an education, you will be limited. Education is first. Stay away from drugs, gangs, etc.

\section{Parental Concerns about Non-Citizen Children}

Parents worried their non-citizen children's life trajectory would resemble their own as foreign-born immigrants lacking legal authorization to reside in the U.S., filled with constraints and worries. One mother noted, "I worry that my sacrifices, my dreams for my daughter are failing. She is already driving like me, without papers. She does not have any more benefits than I do". Parents worried that blocked opportunities would lead to hopelessness and deviance.

Many youth fall prey to drug use, drug trafficking, and many other things because they feel like they are nothing. Even their documented friends bully them because they are not from here or because they lack an I.D., in other words, because they do not have papers.

Parents expressed feeling compelled to ensure their children demonstrated excellent character, prosocial behavior, and responsible conduct. Parents considered that noncitizen children had to be extra careful in how they conducted themselves not to give anyone, particularly police and those in authority positions, a reason to question or intervene. The mother of a 16-year-old boy whom she had brought to the U.S. without legal authorization to reside in the U.S. when he was 6 months old and who had lived continuously in the country since then said,

I try to instill in my son the idea that he has to be very responsible because he is not from this country. I tell him, "Son, your behavior has to be blameless. Do you know why? Because, first, we are not in our own country, and second, people here do not like us. Therefore, if behaving well, they dislike us; imagine if we were to behave badly. Also, whatever we do reflects on the Latino community".

\section{Ambivalence and Coping among Parents in Mixed-Status Families}

The difficulties associated with lacking the authorization to reside in the U.S. and the barriers these created for children's adjustment led some parents to question the decision to bring their foreign-born children to the U.S. A mother 
whose two non-citizen sons had come in contact with the U.S. criminal justice system for drug-related offenses described her feelings this way.

Sometimes, I feel guilty; I start thinking that if I had left my children there [in Mexico], they might have finished school; they might have become somebody. We are from a ranch, a tiny town where there is not much crime or vice [drugs], youth have the chance to go to school. Thus, sometimes, I think that maybe I made a mistake after all, that my children's destiny could have been different.

Seeing their non-citizen children's going through the difficulties that accompany lacking legal authorization to reside in the U.S. was emotionally taxing on parents. Many used the term "heartbreaking" when describing the struggles of their non-citizen children. However, most parents were determined to maintain a sense of hope and sustain their children's dreams and life goals. They felt that, by keeping the family together in the U.S., there was hope for a better future for their citizens and non-citizen children. Thus, the potential for family fragmentation because of a non-citizen parent or sibling's forced deportation was an ongoing concern for parents. Nevertheless, most parents held hope that immigration laws would eventually change. In the meantime, parents mustered their faith and emotional strength to provide a "normal" life to their children and assuage their own and their children's fears for the future.

I try not to think about it [potential deportation]. If I were thinking about that all the time, I would be traumatized; I would not leave my home. Although our situation is frustrating and difficult, I do my best not to fall into a depression. We focus on enjoying our lives while we are here, giving our children our best. We do not want to demonstrate insecurity to them because we want them to grow up feeling secure in themselves, without fear of anything.

\section{Discussion}

This study used a grounded theory approach to understand Latino parents' perceptions of siblings' challenges and opportunities with different legal status. Specifically, we wanted to identify parent perceptions of the challenges faced by their non-U.S. citizen children who are unauthorized aliens. We also sought to identify perceived opportunities afforded to parents' U.S.-born children, who are U.S. citizens, as well as parental concerns about both citizen and noncitizen children and how parents coped with those concerns.
The iterative process of data collection and analysis yielded two broad themes: parental perceptions of children's life trajectories according to U.S. citizenship or lack thereof, and parental concerns regarding their children's mixed legal status. Within the first theme, parents discussed the youth's educational opportunities, job prospects, health care access, and travel restrictions. The second theme encompassed parental concerns about citizen and non-citizen children, ambivalence about migrating to the U.S. and coping with fear and anxiety. Each of the identified themes is integrated with the broader literature to help advance theories of mixedstatus families.

Blocked access to educational opportunities for non-citizen children was a salient concern identified by study participants. Although previous research has documented blocked access to health care (Castañeda \& Melo, 2014), the current results are among the first to highlight all the barriers to academic success experienced by non-citizen children. Lack of educational opportunities for non-citizen children was particularly troublesome for parents because they had moved their children to the U.S. to provide them with good education and access to postsecondary education. Parents acknowledged that when children were young, the educational trajectory of non-citizen children resembled that of citizen children. However, beginning in middle school, these trajectories started diverging. By the time children reached high school, it was evident for parents that non-citizen children's trajectory had stalled. Developmental milestones such as applying for a driver's license and planning for postsecondary education became sources of pain and humiliation for non-citizen children and their parents, paralleling and extending previous research results (Abrego, 2006; Hernandez, 2015).

Although the hardships of raising children in a mixedstatus family are evident, equally apparent is evidence of resilience on the part of Latino parents. The data generated by this study illustrate the remarkable efforts made by parents to provide high levels of both support and demandingness (Baumrind, 2013) for their non-citizen children. Previous evidence suggests that support from parents (Enriquez, 2011; Perez, Espinoza, Ramos, Coronado, \& Cortes, 2009) and parents' high expectations about school (Henry, Merten, Plunkett, \& Sands, 2008) are essential for academic success among Latino youth, including non-citizen students. Given this evidence, the results of this study suggest that immigrant parents, most of whom are lack legal authorization to reside in the U.S., are doing what they can to ensure both their citizen and noncitizen children's academic success. Nevertheless, the data also highlight that parents of youth without legal authorization to reside in the U.S. may be engaging in behaviors, perhaps out of legal necessity, that may impede optimal developmental outcomes for their children. This is an essential area for future research. 
While some parents counted on their children applying for DACA to expand children's educational opportunities, many did not seem to be aware of DACA. This reality is expected to some degree, recognizing these data were collected only 11-15 months after program implementation. The anti-immigrant sentiment of Oklahoma, as evidenced by the passage of House Bill 1804, which some have labeled the most anti-immigrant legislation in the nation (Koralek et al., 2009), further explains the delayed diffusion of knowledge about or participation in DACA. Accordingly, there was substantial confusion about DACA: some parents were not sure whether their children met DACA eligibility requirements, whereas others question if they would be able to obtain the documentation necessary to prove eligibility. Further, the $\$ 465$ cost of the DACA application and biennial renewal was a hardship for many low-income families and an obstacle to applying.

Given the substantial concern about blocked educational pathways evidenced in these data, promoting DACA involvement among eligible individuals would likely support mixed-status families. Indeed, evidence suggests that DACA significantly improves the job prospects and financial standing of non-citizen youth and their families (Hernandez, 2015; Wong \& Valdivia, 2014). Advocacy groups could strengthen their liaisons with local school districts to educate both parents and youth and counselors and school staff about DACA. Despite the opportunities DACA temporarily offered for non-citizen children's educational and employment goals and its indefinite future, it cannot solve the other issues identified by parents in this study, namely health care access and travel restrictions. Mental health care is a frequent unmet health care need reported by DACAeligible young people (Raymond-Flesch et al., 2014), suggesting that whatever form comprehensive immigration reform ultimately assumes, it must give attention to mental health services.

Travel restrictions affected youth's opportunities to participate in out of state and international travel, either school or family-related. Participation in academic and sports tournaments, study abroad, and family travel may foster academic achievement and increase social capital among youth (Fredricks \& Eccles, 2006; Lipscomb, 2007). An additional difficulty for families in the study was non-citizen youth's inability to visit family members in their countries of origin and non-citizen parents' inability to accompany their citizen children on these trips. Far from being a mere nuisance, travel restrictions on family members lacking legal authorization to reside in the U.S. were emotionally trying on the entire family, including citizen and legal permanent resident members, and a marker of social exclusion (Hernandez, 2015; Huber, 2015).

\section{Implications for Future Research}

Since the beginning of this research project, the world has experienced many stressors that may impact the participants' viewpoints in this study. While previous studies have taken place to understand the impact of being an immigrant without legal authorization to reside in the U.S., or those in a mixedstatus family, we note that these families' experiences have likely changed drastically due to the alterations made in immigration approaches and those anticipated under new administrations. We hope studies will continue to characterize the complexities faced by these families, including those brought on by the COVID-19 pandemic. An essential issue for future inquiry are the decision making processes and behaviors parents use to protect their children without legal authorization to reside in the U.S. from legal jeopardy, and the developmental consequences of those decisions. Essentially, is it possible to protect children without legal authorization to reside in the U.S. and their families from legal harm in a manner that eliminates potential impediments to development?

\section{Implications for Practice}

This study provides clinicians with the opportunity to understand individuals' unique experiences with a mixed documentation family status. Family practitioners should strive to provide Latino families with a safe space where they can discuss the issues related to documentation in their lives. However, practitioners should be aware that participants may be afraid to discuss documentation matters openly, and some may never feel safe to do so.

\section{Limitations}

This study has several limitations. The participants were mostly of Mexican origin. Future studies should include participants from other Latin American countries to establish differences among discrete immigrant Latino groups. Most participants were mothers. Fathers' perspectives on the topics covered in the study are necessary to establish whether gender adds a unique perspective to parental perceptions of mixed-status siblings' life trajectories. All participants lived in an urban context in a new Latino destination. Given that rural communities may present particular challenges for immigrant integration and that states are enacting their immigration policies in the absence of comprehensive immigration reform, future studies should include mixed-status families from rural contexts and different receiving communities. Our data collection protocol only produced adults' views on this phenomenon. Future studies should bring adolescents' views on the issues to ensure a theory of family life in mixed-status families relevant to parents and children. Interviews were a one-time 
conversation with the participants. Future studies may consider a transversal approach that may better understand the diverse stages in mixed-status families' lives.

\section{Conclusion}

Distal contexts of development like immigration laws and practices impinge upon proximal ones like the parent-child and sibling relationships to shape vastly different development contexts for citizen and non-citizen children in the U.S. The themes identified in this research point to clear differences in the likely life trajectories of siblings in the same family who differ in terms of their documentation status. Although the actual prevalence and impact of the diverging trajectories identified in this study await future research, the results of this study portend a substantial threat (Castañeda, 2015). A large and rapidly growing segment of U.S. born children live in a mixed-status family, yet very little is known about these families. What is known suggests the consequences of these children and family's legal liminality pose direct risks to children's development and their ability to become productive members of society. Additional research is needed to develop a meaningful and complete theory of mixed-status families; however, overlooking the current situation of the approximately 4.5 million U.S.-born children in a mixed-status family (Passel et al., 2014) is a social experiment that with likely disastrous individual and social consequences.

Acknowledgements This research was supported by the National Institute on Drug Abuse (DA035976).

Funding No funding was received for this study.

\section{Compliance with ethical standards}

Conflict of interest The authors declare no competing of interests.

Ethical approval Data for this study have been collected in an ethical manner. A federally recognized Institutional Review Board approved all sampling, recruitment, and data collection procedures. A Certificate of Confidentiality was obtained from the National Institutes of Health to protect the anonymity of study participants.

Informed consent Informed consent was obtained from all individual participants included in the study.

Publisher's note Springer Nature remains neutral with regard to jurisdictional claims in published maps and institutional affiliations.

\section{References}

Abrego, L. J. (2006). "I can't go to college because I don't have papers": Incorporation patterns of Latino undocumented youth.
Latino Studies, 4(3), 212-231. https://doi.org/10.1057/palgrave. 1st.8600200.

Abrego, L. J. (2011). Legal consciousness of undocumented Latinos: fear and stigma as barriers to claims-making for first- and 1.5generation immigrants. Law \& Society Review, 45(2), 337-370. https://doi.org/10.1111/j.1540-5893.2011.00435.x.

Abrego, L. J. (2019). Relational legal consciousness of U.S. citizenship: priviledge, responsibility, guilt, and love in Latino mixedstatus families. Law \& Society Review, 53(3), 641-670.

Abrego, L. J., \& Gonzales, R. G. (2010). Blocked paths, uncertain futures: the postsecondary education and labor market prospects of undocumented latino youth. Journal of Education for Students Placed at Risk (JESPAR), 15(1-2), 144-157. https://doi.org/10. 1080/10824661003635168.

Alfaro, E. C., Umaña-Taylor, A. J., \& Bámaca, M. Y. (2006). The influence of academic support on Latino adolescents' academic motivation. Family Relations, 55(3), 279-291. https://doi.org/10. 1111/j.1741-3729.2006.00402.x.

Anderson, R. E., \& Stevenson, H. C. (2019). RECASTing racial stress and trauma: theorizing the healing potential of racial socialization in families. American Psychologist, 74(1), 63-75.

Armstrong, M., Birnie-Lefcovitch, S., \& Ungar, M. (2005). Pathways between social support, family well being, quality of parenting, and child resilience: What we know. Journal of Child \& Family Studies, 14(2), 269-281. https://doi.org/10.1007/s10826-005-5054-4.

Bámaca, M. Y., Umaña-Taylor, A. J., Shin, N., \& Alfaro, E. C. (2005). Latino adolescents' perception of parenting behaviors and selfesteem: examining the role of neighborhood risk. Family Relations, 54(5), 621-632. https://doi.org/10.1111/j.1741-3729.2005. 00346.x.

Baumrind, D. (2013). Authoritative parenting revisited: History and current status. In R. E. Larzelere, A. S. Morris \& A. W. Harrist (Eds.), Authoritative parenting: Synthesizing nurturance and discipline for optimal child development. American Psychological Association.

Bronfenbrenner, U. (1979). The ecology of human development: Experiments by nature and design. Harvard University Press.

Castañeda, H., \& Melo, M. A. (2014). Health care access for Latino mixed-status families: Barriers, strategies, and implications for reform. American Behavioral Scientist, 58(14), 1891-1909. https://doi.org/10.1177/0002764214550290.

Castañeda, H., Holmes, S. M., Madrigal, D. S., Young, M.-E. D., Beyeler, N., \& Quesada, J. (2015). Immigration as a Social Determinant of Health. Annual Review of Public Health, 36(1), 375-392. https://doi.org/10.1146/annurev-publhealth-032013182419.

Castañeda, H. (2015). Mixed-status families in the Rio Grande Valley of Texas: Health Disparities and Life along the U.S./Mexico Border. In A. Schueths \& J. Lawston (Eds.), In between the shadows of citizenship: Mixed status families (pp. 106-118). University of Washington Press.

Castro-Salazar, R., \& Bagley, C. (2010). 'Ni de aquí ni from there'. Navigating between contexts: counter-narratives of undocumented Mexican students in the United States. Race Ethnicity and Education, 13(1), 23-40. https://doi.org/10.1080/136133209 03549651.

Chavez, J. M., Lopez, A., Englebrecht, C. M., \& Viramontez Anguiano, R. P. (2012). Sufren los niños: Exploring the impact of unauthorized immigration status on children's well-being. Family Court Review, 50(4), 638-649. https://doi.org/10.1111/j.17441617.2012.01482.x.

Corbin, J., \& Strauss, A. (1990). Grounded theory research: Procedures, canons, and evaluative criteria. Qualitative. Sociology, 13 (1), 3-21. 
Corbin, J. M., \& Strauss, A. L. (2008). Basics of qualitative research: Techniques and procedures for developing grounded theory. SAGE Publications.

Creswell, J. W. (2007). Qualitative inquiry \& research design: Choosing among five approaches. SAGE Publications.

Eisenberg, N., Zhou, Q., Spinrad, T. L., Valiente, C., Fabes, R. A., \& Liew, J. (2005). Relations among positive parenting, children's effortful control, and externalizing problems: A three-wave longitudinal study. Child Development, 76(5), 1055-1071. https://doi.org/10.1111/j.1467-8624.2005.00897.x.

Elder, G. H. (1998). Children of the Great Depression: 25th Anniversary Edition. Westview Press.

Elgar, F., Mills, R. L., McGrath, P., Waschbusch, D., \& Brownridge, D. (2007). Maternal and paternal depressive symptoms and child maladjustment: The mediating role of parental behavior. Journal of Abnormal Child Psychology, 35(6), 943-955. https://doi.org/ 10.1007/s10802-007-9145-0.

Enriquez, L. (2011). "Because we feel the pressure and we also feel the support": Examining the educational success of undocumented immigrant Latina/o students. Harvard Educational Review, 81(3), 476-500. https://doi.org/10.17763/haer.81.3.w7k703q050143762.

Fosco, G. M., \& Grych, J. H. (2013). Capturing the family context of emotion regulation: A family systems model comparison approach. Journal of Family Issues, 34(4), 557-578. https://doi. org/10.1177/0192513x12445889.

Fredricks, J. A., \& Eccles, J. S. (2006). Is extracurricular participation associated with beneficial outcomes? Concurrent and longitudinal relations. Developmental Psychology, 42(4), 698-713. https://doi. org/10.1037/0012-1649.42.4.698.

Furman, R., Negi, N. J., Iwamoto, D. K., Rowan, D., Shukraft, A., \& Gragg, J. (2009). Social work practice with Latinos: Key issues for social workers. Social Work, 54(2), 167-174.

Gonzales, R. G. (2010). On the wrong side of the tracks: Understanding the effects of school structure and social capital in the educational pursuits of undocumented immigrant students. Peabody Journal of Education, 85(4), 469-485. https://doi.org/10. 1080/0161956X.2010.518039.

Gonzales, R. G. (2011). Learning to be illegal undocumented youth and shifting legal contexts in the transition to adulthood. American Sociological Review, 76(4), 602-619. https://doi.org/10. 1177/0003122411411901.

Gonzales, R. G., Suárez-Orozco, C., \& Dedios-Sanguineti, M. C. (2013). No place to belong: Contextualizing concepts of mental health among undocumented immigrant youth in the United States. American Behavioral Scientist, 57(8), 1174-1199. https:// doi.org/10.1177/0002764213487349.

Gonzales, R. G., Terriquez, V., \& Ruszczyk, S. P. (2014). Becoming DACAmented: Assessing the short-term benefits of deferred action for childhood arrivals (DACA). American Behavioral Scientist, 58(14), 1852-1872.

Gonzales, R. G., \& Suárez-Orozco, M. M. (2009). Young lives on hold: The college dreams of undocumented students. College Board.

Gonzalez, A. R., Doan Holbein, M. F., \& Quilter, S. (2002). High school students' goal orientations and their relationship to perceived parenting styles. Contemporary Educational Psychology, 27(3), 450-470. https://doi.org/10.1006/ceps.2001.1104.

Gonzalez, A.-L., \& Wolters, C. A. (2006). The relation between perceived parenting practices and achievement motivation in mathematics. Journal of Research in Childhood Education, 21 (2), 203-217. https://doi.org/10.1080/02568540609594589.

Gonzalez-DeHass, A. R., Willems, P. P., \& Holbein, M. F. D. (2005). Examining the relationship between parental involvement and student motivation. Educational Psychology Review, 17(2), 99-123. https://doi.org/10.1007/s10648-005-3949-7.
Greenman, E., \& Hall, M. (2013). Legal status and educational transitions for Mexican and Central American immigrant youth. Social Forces, 91(4), 1475-1498. https://doi.org/10.1093/sf/ sot040.

Grusec, J. E. (2011). Socialization processes in the family: Social and emotional development. Annual Review of Psychology, 62(1), 243-269. https://doi.org/10.1146/annurev.psych.121208.131650.

Henry, C. S., Merten, M. J., Plunkett, S. W., \& Sands, T. (2008). Neighborhood, parenting, and adolescent factors and academic achievement in Latino adolescents from immigrant families. Family Relations, 57(5), 579-590. https://doi.org/10.1111/j.17413729.2008.00524.x.

Hernandez, H. (2015). An interpretative phenomenological analysis of the identity of undocumented Mexican-origin adolescents living in California. (Dissertation). The wright Institute, Berkeley, CA. Retrieved from http://gradworks.umi.com/36/63/3663036.html.

Hernández, M. G., Nguyen, J., Casanova, S., Suárez-Orozco, C. \& Saetermoe, C. L. (2013). Doing no harm and getting it right: Guidelines for ethical research with immigrant communities. New Directions for Child and Adolescent Development, 43-60. https:// doi.org/10.1002/cad.20042.

Huber, L. P. (2015). Como una jaula de oro (it's like a golden cage): The impact of DACA and the California Dream Act on documented Chicanas/Latinas. Chicana/o-Latinalo Review, 3(1), 91-128.

Koralek, R., Pedroza, J., \& Capps, R. (2009). Untangling the Oklahoma Taxpayer and Citizen Protection Act: Consequences for Children and Families. Washington, DC: National Council of La Raza. Retrieved from https://www.urban.org/sites/default/files/ publication/27981/1001356-Untangling-the-Oklahoma-Taxpayer -and-Citizen-Protection-Act-Consequences-for-Children-and-Fa milies.PDF.

Leidy, M. S., Guerra, N. G., \& Toro, R. I. (2010). Positive parenting, family cohesion, and child social competence among immigrant Latino families. Journal of Family Psychology, 24(3), 252-260. https://doi.org/10.1037/a0019407.

Lincoln, Y. S., \& Guba, E. G. (1985). Naturalistic Inquiry. SAGE Publications.

Link, B., \& Phelan, J. (1995). Social conditions as fundamental causes of disease. Journal of Health and Social Behavior, 35, 80-94. https://doi.org/10.2307/2626958.

Lipscomb, S. (2007). Secondary school extracurricular involvement and academic achievement: a fixed effects approach. Economics of Education Review, 26(4), 463-472. https://doi.org/10.1016/j. econedurev.2006.02.006.

Mahalingam, R. \& Rabelo, V. C. (2013). Theoretical, methodological, and ethical challenges to the study of immigrants: Perils and possibilities. New Directions for Child and Adolescent Development, 25-41. https://doi.org/10.1002/cad.20041.

Mangual Figueroa, A. (2013). ¡Hay que hablar!: Testimonio in the everyday lives of migrant mothers. Language \& Communication, 33(4), 559-572. https://doi.org/10.1016/j.langcom.2013.03.011.

Menjívar, C. (2006). Liminal legality: Salvadoran and Guatemalan immigrants' lives in the United States. American Journal of Sociology, 111(4), 999-1037.

Miles, M. B., \& Huberman, A. M. (1994). Qualitative data analysis: An expanded sourcebook. SAGE Publications.

Milevsky, A., Schlechter, M., Netter, S., \& Keehn, D. (2007). Maternal and paternal parenting styles in adolescents: Associations with self-esteem, depression and life-satisfaction. Journal of Child and Family Studies, 16(1), 39-47. https://doi.org/10.1007/ s10826-006-9066-5.

Morris, A. S., Cui, L., \& Steinberg, L. (2013). Parenting research and themes: What we have learned and where to go next. In R. E. Larzelere, A. S. Morris \& A. W. Harrist (Eds.), Authoritative 
parenting: Synthesizing nurturance and discipline for optimal child development. American Psychological Association.

Motomura, H. (2006). Americans in waiting: The lost story of immigration and citizenship in the United States. Oxford University Press.

Ortega, A. N., Horwitz, S. M., Fang, H., Kuo, A. A., Wallace, S. P., \& Inkelas, M. (2009). Documentation status and parental concerns about development in young U.S. children of Mexican origin. Academic Pediatrics, 9(4), 278-282. https://doi.org/10.1016/j.aca p.2009.02.007.

Passel, J. S., Cohn, D., Krogstad, J. M., \& Gonzalez-Barrera, A. (2014). As growth stalls, unauthorized immigrant population becomes more settled. Washington, DC: Pew Hispanic Center.

Patler, C., Hamilton, E., Meagher, K., \& Savina, R. Uncertainty about DACA may undermine its positive impact on health for recipients and their children. Health Affairs, 38(5), 738-745.

Perez, W., Espinoza, R., Ramos, K., Coronado, H. M., \& Cortes, R. (2009). Academic resilience among undocumented latino students. Hispanic Journal of Behavioral Sciences, 31(2), 149-181. https://doi.org/10.1177/0739986309333020.

Pew Hispanic Center. (2013). A statistical portrait of U.S. Hispanics. Retrieved June 28, 2015, from http://www.pewhispanic.org/2013/ 02/15/hispanic-population-trends/ph_13-01-23_ss_hispanics1/

Plunkett, S. W., Williams, S. M., Schock, A. M., \& Sands, T. (2007). Parenting and adolescent self-esteem in Latino intact families, stepfather families, and single-mother families. Journal of Divorce \& Remarriage, 47(3-4), 1-20. https://doi.org/10.1300/ J087v47n03_01.

Plunkett, S. W., Henry, C. S., Houltberg, B. J., Sands, T., \& AbarcaMortensen, S. (2008). Academic support by significant others and educational resilience in Mexican-origin ninth grade students from intact families. Journal of Early Adolescence, 28(3), 333-355. https://doi.org/10.1177/0272431608314660.

Raymond-Flesch, M., Siemons, R., Pourat, N., Jacobs, K., \& Brindis, C. D. (2014). "There is no help out there and if there is, it's really hard to find": A qualitative study of the health concerns and health care access of Latino "DREAMers". Journal of Adolescent Health, 55(3), 323-328. https://doi.org/10.1016/j.jadohealth.2014.05.012.

Rutter, M. (2005). How the environment affects mental health. The British Journal of Psychiatry, 186(1), 4-6. https://doi.org/10. 1192/bjp.186.1.4.

Sigel, I. E., McGillicuddy-DeLisi, A. V., \& Goodnow, J. J. (2014). Parental belief systems: The psychological consequences for children. Psychology Press.

Spinrad, T. L., Eisenberg, N., Gaertner, B., Popp, T., Smith, C. L., Kupfer, A., \& Hofer, C. (2007). Relations of maternal socialization and toddlers' effortful control to children's adjustment and social competence. Developmental Psychology, 43(5), 1170-1186. https://doi.org/10.1037/0012-1649.43.5.1170.

Steinberg, L., \& Morris, A. S. (2001). Adolescent development. Journal of Cognitive Education and Psychology, 2(1), 55-87. https://doi.org/10.1891/194589501787383444.

Strauss, A., \& Corbin, J. (1990). Basics of qualitative research: Grounded Theory Procedures and Techniques (Second Edition edition). SAGE Publications.

Suárez-Orozco, C., Motti-Stefanidi, F., Marks, A., \& Katsiaficas, D. (2018). An integrative risk and resilience model for understanding the adaption of immigrant-origin children and youth. American Psychologist, 73(6), 781-796.

Suárez-Orozco, C., \& Yoshikawa, H. (2013). Undocumented status: Implications for child development, policy, and ethical research. New Directions for Child and Adolescent Development, 2013 (141), 61-78. https://doi.org/10.1002/cad.20043.

Suárez-Orozco, C., Yoshikawa, H., Teranishi, R., \& Suárez-Orozco, M. (2011). Growing up in the shadows: The developmental implications of unauthorized status. Harvard Educational Review, 81(3), 438-473. https://doi.org/10.17763/haer.81.3. g23×203763783m75.

Swanson, J., Valiente, C., Lemery-Chalfant, K., \& Caitlin O'Brien, T. (2011). Predicting early adolescents' academic achievement, social competence, and physical health from parenting, ego resilience, and engagement coping. Journal of Early Adolescence, 31(4), 548-576. https://doi.org/10.1177/0272431610366249.

Taylor, P., Lopez, M. H., Passel, J. S., \& Motel, S. (2011). Unauthorized immigrants: Length of residency, patterns of parenthood. Pew Hispanic Center.

Wong, T. K., \& Valdivia, C. (2014). In their own words: A nationwide survey of undocumented millennials. Working paper (Vol. 191). La Jolla, CA: U.C. Center for Comparative Immigration Studies.

Yamamoto, Y., \& Holloway, S. (2010). Parental expectations and children's academic performance in sociocultural context. Educational Psychology Review, 22(3), 189-214. https://doi.org/10. 1007/s10648-010-9121-z.

Yoshikawa, H. \& Way, N. (2008). From peers to policy: How broader social contexts influence the adaptation of children and youth in immigrant families. New Directions for Child and Adolescent Development, 1-8. https://doi.org/10.1002/cd.219.

Yoshikawa, H., Godfrey, E. B. \& Rivera, A. C. (2008). Access to institutional resources as a measure of social exclusion: Relations with family process and cognitive development in the context of immigration. New Directions for Child and Adolescent Development, 63-86. https://doi.org/10.1002/cd.223. 